\title{
Ancient DNA Reveals Genetic Continuity in Mountain Woodland Caribou of the Mackenzie and Selwyn Mountains, Northwest Territories, Canada \\ BRANDON LETTS, ${ }^{1}$ TARA L. FULTON, ${ }^{1}$ MATHIAS STILLER, ${ }^{1}$ THOMAS D. ANDREWS, ${ }^{2}$ GLEN MacKAY, RICHARD POPKO ${ }^{3}$ and BETH SHAPIRO ${ }^{1,4}$
}

(Received 22 February 2011; accepted in revised form 10 June 2011)

\begin{abstract}
We examine the mitochondrial genetic stability of mountain woodland caribou (Rangifer tarandus caribou) in the Mackenzie and Selwyn Mountains, Northwest Territories, over the last 4000 years. Unlike caribou populations in the Yukon, populations in the Northwest Territories show no evidence for mitochondrial genetic turnover during that period, which indicates that they were not adversely affected by the widespread deposition of the White River tephra around 1200 years ago. We detect moderate genetic differentiation between mountain woodland and barren-ground caribou in both territories, lending support to the current subspecies designations. In addition, we identify moderate genetic differentiation between Northwest Territories and western Yukon mountain woodland caribou, suggesting that there has been minimal mixing of matrilines between these herds.
\end{abstract}

Key words: ice patch, Redstone herd, ecotype, White River tephra, mitochondrial, barren-ground

RÉSUMÉ. Nous examinons la stabilité génétique mitochondriale des caribous des bois des montagnes (Rangifer tarandus caribou) qui ont évolué dans les monts Mackenzie et dans la chaîne de Selwyn, Territoires du Nord-Ouest, ces 4000 dernières années. Contrairement aux populations de caribou du Yukon, les populations de caribou des Territoires du Nord-Ouest ne montrent aucun signe de rotation génétique mitochondriale pendant cette période, ce qui indique qu'ils n'ont pas été affectés de manière défavorable par le dépôt à grande échelle du téphra de la rivière White, il y a environ 1200 ans. Nous détectons une différentiation génétique modérée entre le caribou des bois des montagnes et le caribou de la toundra dans les deux territoires, ce qui vient appuyer les désignations actuelles de sous-espèces. Par ailleurs, nous avons dénoté une différenciation génétique modérée entre le caribou des bois des montagnes des Territoires du Nord-Ouest et celui de l'ouest du Yukon, ce qui laisse croire qu'il y aurait eu peu de mélanges matrilinéaires entre ces troupeaux.

Mots clés : névé, troupeau de Redstone, écotype, téphra de la rivière White, mitochondrial, toundra

Traduit pour la revue Arctic par Nicole Giguère.

\section{INTRODUCTION}

Caribou (Rangifer tarandus) have inhabited the Arctic since the Pleistocene (Flagstad and Røed, 2003). After the last glacial maximum, the barren-ground and woodland caribou of Alaska and Canada expanded out of Beringia into their current ranges (Zittlau, 2004). Anthropogenic habitat fragmentation is now placing unprecedented pressure on the mountain woodland caribou, leading the Canadian government to classify the southern mountain caribou as threatened and the northern mountain caribou as a species of special concern (Bergerud, 1974; COSEWIC, 2002; McLoughlin et al., 2003).

Caribou are holarctic in distribution, ranging across North America, Greenland, Europe, and Siberia. They form herds of dozens to hundreds of thousands of individuals, depending on ecotype. In the Canadian Yukon Territory (YT) and Northwest Territories (NWT), three subspecies are recognized (Flagstad and Røed, 2003). The barrenground caribou (Rangifer tarandus groenlandicus in the NWT; $R$. t. granti in the YT and Alaska) inhabit the open tundra, sometimes forming herds of hundreds of thousands of individuals. These herds are known to migrate as far as $4000 \mathrm{~km}$ between seasonal ranges (Zittlau, 2004). In contrast, woodland caribou (R. t. caribou) form smaller herds that inhabit the boreal forests. Depending on their habitat, these herds are considered either mountain woodland or boreal woodland caribou (Olsen et al., 2001).

Along the YT-NWT border, several mountain woodland caribou herds inhabit the areas around and within the Mackenzie and Selwyn Mountains (Fig. 1; Yukon Geomatics, 2008). During calving season, these herds are largely

\footnotetext{
${ }^{1}$ Department of Biology, Pennsylvania State University, 320 Mueller Laboratory, University Park, Pennsylvania 16802, USA

${ }^{2}$ Prince of Wales Northern Heritage Centre, PO Box 1320, Yellowknife, Northwest Territories X1A 2L9, Canada

${ }^{3}$ Environment and Natural Resources, Sahtu Region, PO Box 130, Norman Wells, Northwest Territories X0E 0V0, Canada

${ }^{4}$ Corresponding author: beth.shapiro@gmail.com

(C) The Arctic Institute of North America
} 


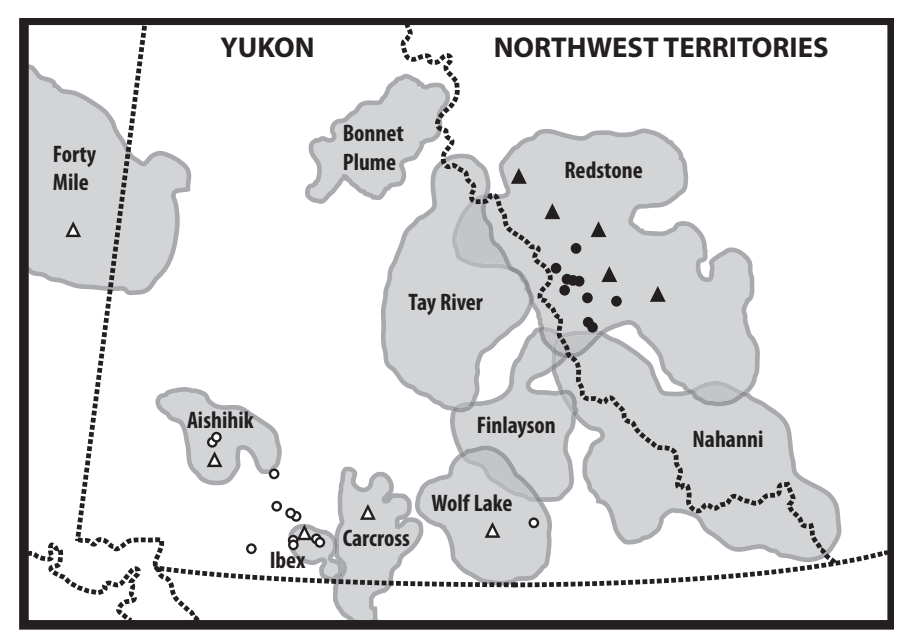

FIG. 1. Ranges of the caribou herds represented in this study. Mitochondrial DNA is available from the Redstone, Wolf Lake, Ibex, Aishihik, and Fortymile herds (Table 1). Ranges for the neighbouring herds of Bonnet Plume, Nahanni, Finlayson, and Tay River are also shown. The circles represent ancient ice patch specimens, and the triangles represent modern specimens. Closed symbols $(\boldsymbol{\Lambda}, \boldsymbol{\bullet})$ represent the locations of new specimens, while open symbols $(\triangle, O)$ represent those of sequences acquired in previous studies.

isolated from one another. However, genetic analyses suggest that these herds may actually function as a single large herd, or metapopulation (Zittlau, 2004). Understanding the relationships between these herds has important consequences, as long-term caribou conservation policy should be based on metapopulation dynamics rather than herd dynamics (Hinkes et al., 2005).

During the summer months, caribou are known to use perennial alpine ice patches to keep cool and escape insect harassment (Ion and Kershaw, 1989). These ice patches are continuously replenished by snowfall during the winter and are effectively permanent, although recent surveys have shown they are shrinking in the Yukon (Farnell et al., 2004). Numerous ice patches have been discovered within the current caribou range in the YT and NWT, including several in the Mackenzie and Selwyn Mountains (Andrews et al., 2012). These ice patches preserve a record of local caribou occupation over thousands of years in the form of dung and bones incorporated into the ice layers (Farnell et al., 2004; Andrews et al., 2012). Radiocarbon dating of fecal material from the NWT ice patches revealed the continuous presence of caribou in the region over the last 4500 years (Andrews et al., 2012).

Recently, melt-out of the ice patches released bones that had been frozen since deposition, providing the opportunity to use ancient DNA (aDNA) techniques to examine the population dynamics of caribou in this region through time. Ancient DNA can permit the direct observation of how populations responded to past periods of environmental change (Leonard, 2008). Such information can provide a crucial temporal perspective, which has been shown to facilitate the most effective conservation strategies (Willis and Birks, 2006).

We use ancient mitochondrial DNA isolated from bones recovered from the NWT ice patches to infer the recent evolutionary history of the caribou populations from these regions. Mitochondrial DNA is a maternally inherited genetic locus that is favoured in ancient DNA analyses because (1) it is at a much higher copy-number per cell than is nuclear genetic DNA, and therefore it is much more likely to be preserved through time (Willerslev and Cooper, 2005); and (2) it does not recombine, and therefore the evolutionary history of this locus is relatively simple to infer compared to that of nuclear genetic loci (Rokas et al., 2003).

We address four questions about the recent population dynamics of caribou in the Mackenzie and Selwyn Mountains. First, we assess whether the mountain woodland caribou in the central Mackenzie and Selwyn Mountains, NWT, comprise a single, large herd: the Redstone herd (Fig. 1). If this is the case, we expect to find a single, homogenous population. Alternatively, the traditional Redstone herd could be a metapopulation composed of several herds sharing a common range (Olsen et al., 2001). In this case, we expect to see distinct genetic clusters related to the geographic proximity of the individuals.

Second, we address the temporal stability of the NWT mountain woodland caribou populations. We propose that ancient caribou using the NWT ice patches are the ancestors of the modern Redstone herd. This assumes that the deposition of the White River tephra (volcanic ashfall) around 1200 years ago (Froese et al., 2007) did not force caribou to move out of the area, as has been shown for caribou living in the Southern Lakes region, YT, where more ash was deposited than in the NWT (Lerbekmo, 2008; Kuhn et al., 2010).

Third, we explore whether or not the mountain woodland caribou of the NWT and of YT are genetically distinct from one another. It has been proposed (Kuhn et al., 2010) that the ancient caribou populations that previously resided in the southwestern YT (Fig. 1) are genetically distinct from the populations currently residing in the same area of the YT. If the ancient NWT mountain woodland caribou are genetically distinct from the ancient YT caribou, but not from the modern YT caribou, then the NWT mountain woodland caribou could represent a potential source population for the modern YT caribou.

Fourth, we test for genetic differentiation corresponding to ecotype within the region-mountain woodland form (R. t. caribou) vs. continental tundra form (R. t. groenlandicus, Canadian barren-ground; $R$. t. granti, Alaska caribou) - and between subspecies within the NWT (R. $t$. groenlandicus v. R. t. caribou). We expect to see no genetic differentiation, as previous studies have failed to identify mitochondrial differentiation between these ecotypes or subspecies (Flagstad and Røed, 2003; Kuhn et al., 2010). We propose that this lack of differentiation is not a modern phenomenon, and that the two ecotypes either shared a very recent common ancestor or have undergone considerable recent admixture. However, genetic differentiation may exist, as herds belonging to each of the two ecotypes are unlikely to experience significant mixing. 


\section{MATERIALS AND METHODS}

\section{Sample Collection}

Between 2005 and 2008, 17 caribou bones and teeth were collected from 11 ice patches in the Mackenzie and Selwyn Mountains of the western NWT, Canada, along the border with the YT (Andrews et al., 2012). A modern antler was also collected from an ice patch and sampled for DNA. Radiocarbon $\left({ }^{14} \mathrm{C}\right)$ dates on ancient specimens yielded ages ranging from a few hundred to almost 4000 years (Table 1). Dates are reported as radiocarbon years before present (BP), calibrated with the IntCal09 curve (Reimer et al., 2009) using CALIB 6.0 (Stuiver and Reimer, 1993).

To assess changes in the mitochondrial genetic diversity of caribou living in the region over time, we obtained 38 hair samples from the Northwest Territories Department of Environment and Natural Resources that had been collected from caribou killed in defined outfitter (hunting) zones (Fig. 2). Although none of the hair specimens we obtained were attributed to any particular herd, they likely belonged to one of three: the mountain woodland Redstone herd, whose range overlaps all outfitter zones and ice patches from which samples were obtained; the Bonnet Plume herd, which is present in the western part of outfitter zone S/OT/01; and the Carcajou herd, which may overlap the eastern part of outfitter zone S/OT/01.

The ice patches yielding ancient caribou remains fall mainly within the Ram Head outfitter zone S/OT/03, from which we obtained 10 modern samples. The study area over which ice patches have been discovered also includes the Mackenzie Mountain outfitter zone S/OT/02 (represented in our study by 9 modern samples) in the north, and the NWT outfitter zone S/OT/04 (represented by 9 modern samples) in the south. The Gana River outfitter zone S/OT/01 (represented by 4 modern samples) borders the study area to the north, while the Redstone outfitter zone S/OT/05 (represented by 4 modern samples) borders the study area to the southeast. No samples from the Nahanni Butte outfitter zone (D/OT/02) or the South Nahanni outfitter zone (D/OT/01) were available.

\section{Sample Processing}

DNA Extraction from Ancient Specimens: We processed all ancient samples following standard protocols for working with ancient DNA (Cooper and Poinar, 2000). For example, we performed all DNA extraction and preamplification steps in a sterile, dedicated laboratory that is spatially isolated from other molecular biology research at the Pennsylvania State University. We used multiple negative controls during both the DNA extraction and PCR phases, and we cloned samples to assess both DNA damage and contamination by exogenous sources.

We prepared powder samples from ancient bones and teeth using a Dremel tool equipped with a cutting disk and a Mikrodismembrator (B. Braun Biotech International) for pulverization. We extracted DNA following a silica-based protocol (Rohland et al., 2009), using no more than $500 \mathrm{mg}$ of bone powder from each sample. We eluted the aDNA extracts in a final concentration of $50 \mu \mathrm{l}$ of TE buffer.

DNA Extraction from Modern Specimens: We processed the hair sampled from living caribou in the modern molecular biology facility after all ancient caribou work had been completed, so as to avoid the possibility of contamination of ancient extracts with modern caribou DNA. We use the Qiagen DNeasy Blood and Tissue kit (Qiagen, Inc.) with several modifications to more efficiently digest hair: we doubled the amount of lysis buffer ATL, increased the amount of proteinase $\mathrm{K}$ from $20 \mu \mathrm{l}$ to $30 \mu \mathrm{l}$, and added $20 \mu \mathrm{l}$ of 1M DTT to promote lysis of the hair shafts. Incubation was carried out overnight at $56^{\circ} \mathrm{C}$. Because of the increased volume of the extraction mixture, it was also necessary to double the amount of buffer AL and ethanol during the silica-binding and wash phases. Samples were eluted in $150 \mu$ l of buffer TE.

DNA Amplification from Ancient Specimens: We amplified the entire $564 \mathrm{bp}$ (base pair) fragment of caribou mitochondrial control region hypervariable segment 1 using a single primer pair (CBF1/CB5R; Kuhn et al., 2010). Prior to amplification, we added $2 \mu \mathrm{l}$ of Tween 20 (Sigma-Aldrich) to each $\sim 50 \mu 1$ extract. We performed PCR in $25 \mu \mathrm{l}$ reactions using Platinum Taq High Fidelity DNA polymerase (Invitrogen), with the following components and final concentrations: $2 \mathrm{mM} \mathrm{MgSO}{ }_{4}, 250 \mu \mathrm{M}$ dNTPs, $1 \mu \mathrm{M}$ primers, $2 \mathrm{mg} / \mathrm{ml}$ rabbit serum albumin (Sigma-Aldrich). Cycling conditions were $94^{\circ} \mathrm{C}$ for $60 \mathrm{~s}$, followed by 55 cycles of $94^{\circ} \mathrm{C}$ for $30 \mathrm{~s}, 63^{\circ} \mathrm{C}$ for $45 \mathrm{~s}$, and $68^{\circ} \mathrm{C}$ for $45 \mathrm{~s}$. PCR products were resolved on a $2 \%$ agarose gel and visualized using ethidium bromide and UV transillumination. Amplification was successful for all extracts, and no PCR products were observed in the negative extraction or amplification controls.

To assess DNA damage and screen ancient specimens for contamination, we cloned all but one sample using the TOPO TA cloning kit (Invitrogen) according to manufacturers' instructions. Six clones from each sample were sequenced using the M13F(-20) primer (TOPO manual).

DNA Amplification from Modern Specimens: For the modern specimens, we amplified the same $564 \mathrm{bp}$ fragment used in the aDNA analysis. Reactions were performed in $25 \mu 1$ reactions using GoTaq Flexi DNA polymerase (Promega), with the following components and final concentrations: $2 \mathrm{mM} \mathrm{MgCl} 2,250 \mu \mathrm{M}$ dNTPs, $1 \mu \mathrm{M}$ primers. Cycling conditions were $94^{\circ} \mathrm{C}$ for $60 \mathrm{~s}$, followed by 35 cycles of $94^{\circ} \mathrm{C}$ for $1 \mathrm{~min}, 63^{\circ} \mathrm{C}$ for $1 \mathrm{~min}, 72^{\circ} \mathrm{C}$ for $2 \mathrm{~min}$, and a final extension of $72^{\circ} \mathrm{C}$ for $10 \mathrm{~min}$. Sequencing of amplified products was performed using $\mathrm{CB} 1 \mathrm{~F}$ and two nested sequencing primers CARseqF (5, TAAACTATTCCCTGGCG 3') and CARseqR (5' AATAGCTACCCCCACAG 3'). All sequencing reactions were performed using the BigDye v3.1 chemistry (Applied Biosystems) and resolved on an ABI 3730xl capillary sequencer at the Penn State Genomics Core Facility (University Park, PA). 


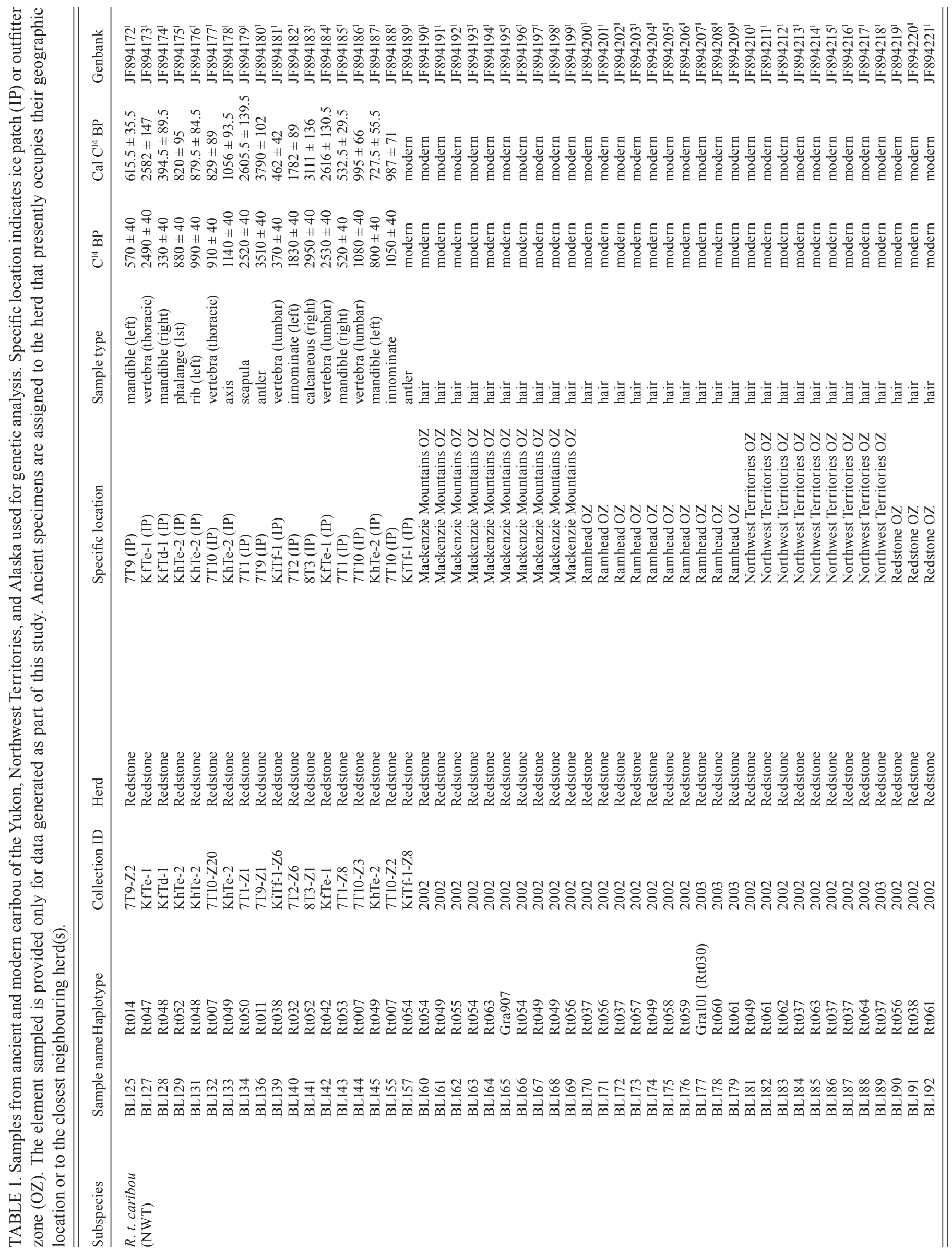


84 - B. LETTS et al.

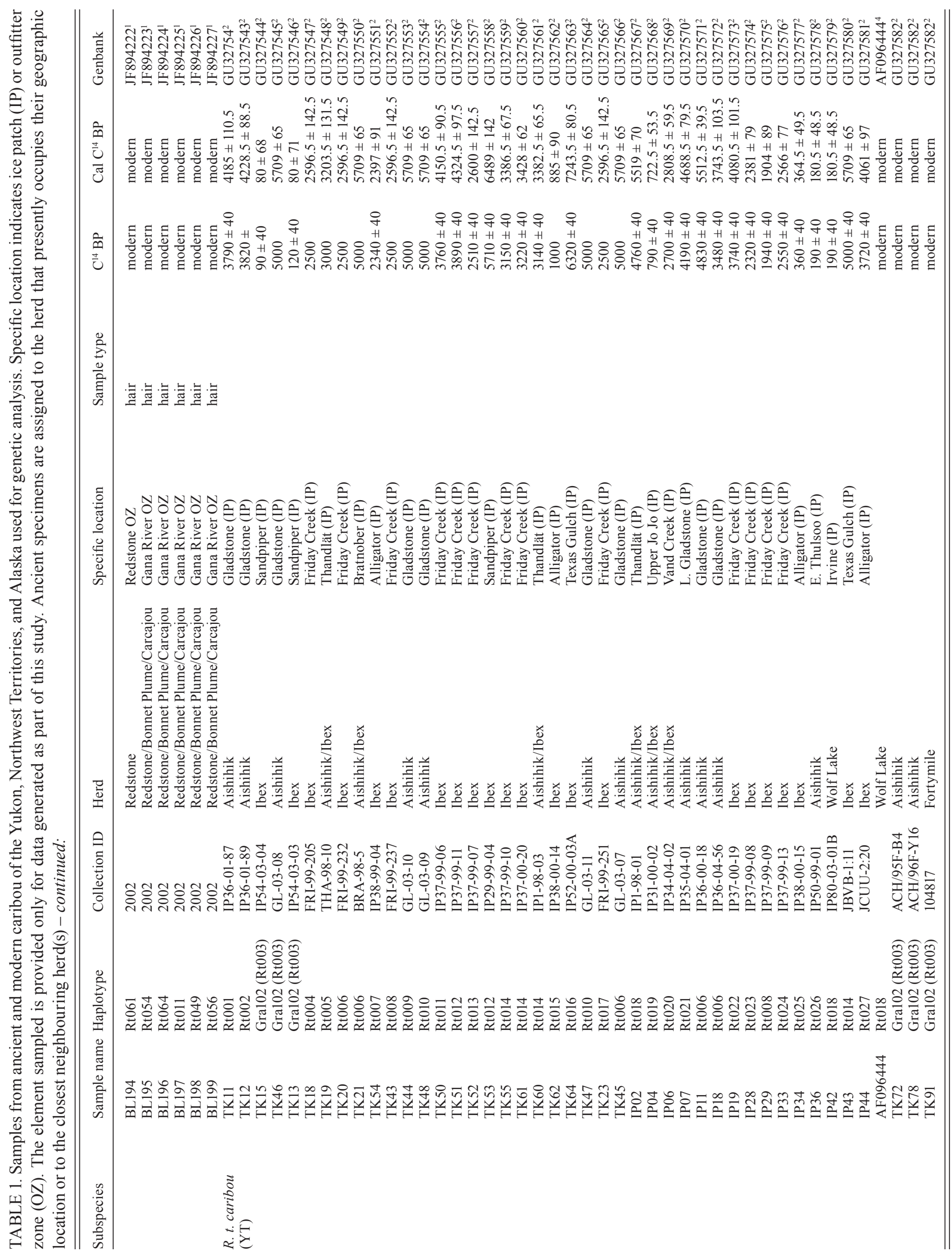




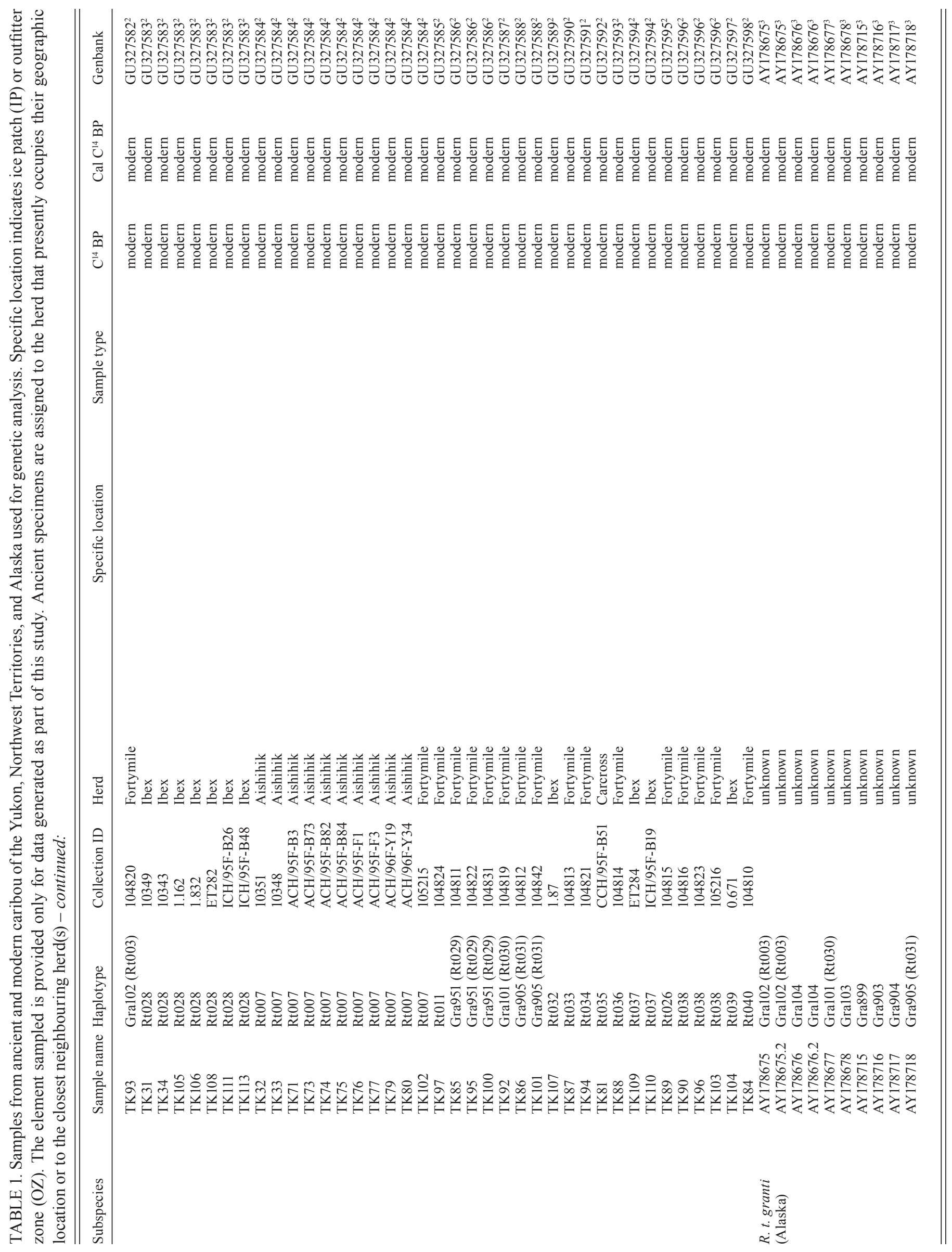




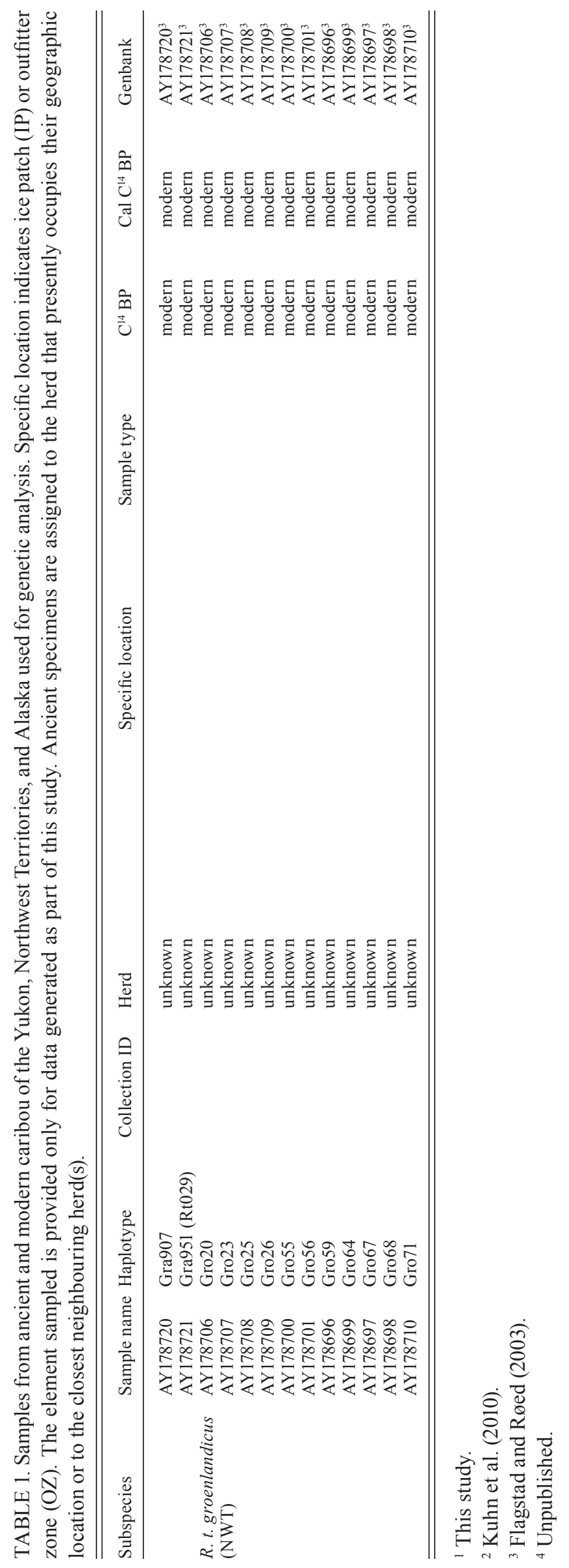

\section{Genetic Analysis}

We used the Lasergene Suite (DNAStar) software to align sequences and checked the alignments by eye in Se-Al version 2.0a11 (Rambaut, 2002). To expand the geographic range of our data set, we obtained 106 additional, previously published caribou sequences from Genbank, including 11 NWT barren-ground caribou, 30 YT barrenground caribou, and 65 modern and ancient YT northern mountain woodland caribou (Table 1) corresponding to five recognized herds (Table 2). The final alignment length was $503 \mathrm{bp}$.

To identify population structure, we constructed a median-joining network using Network v4.6.0.0 (Bandelt et al., 1999). Twelve sequences (TK31, TK34, TK105, TK106, TK108, TK111, TK113, TK45, TK61, AY178708, AY178701, AY178700) containing ambiguous nucleotides were not included in the analysis, as recommended by the Network user manual. In addition, to achieve less than 5\% missing data for each nucleotide position in the alignment, while maintaining as much data (alignment length) and as many individuals as possible, seven modern NWT individuals (BL164, BL170, BL172, BL178, BL184, BL189, BL196) were removed.

To incorporate the spatial and temporal aspect of our data, we used BEAST v1.6.1 (Drummond and Rambaut, 2007), which allows the explicit use of sample dates in a coalescent-based genealogical inference framework. We selected the best-fitting evolutionary model using jModeltest v0.1.1 (Guindon and Gascuel, 2003; Posada, 2008). BEAST analyses were performed using the HKY model of nucleotide substitution (Hasegawa et al., 1985) with gamma distributed rate heterogeneity and assuming a strict molecular clock and constant population size coalescent prior. We simulated one MCMC run for 50 million iterations, drawing samples from the posterior every 5000 iterations. We used Tracer v1.5 (Drummond and Rambaut, 2007) to check that estimated sample sizes of all parameters were sufficient (ESS > 200) and to verify that the parameter estimates had reached stationarity. The maximum clade credibility (MCC) tree was calculated using treeAnnotator, following removal of the initial $10 \%$ of samples as burn-in.

Finally, to measure genetic differentiation between predefined groups, we used Arlequin v3.5.1.2 (Excoffier and Lischer, 2010) to calculate FST values and to perform a standard AMOVA (Analysis of MOlecular Variance; Weir and Cockerham, 1984), which calculates the degree of genetic variation attributable to among-group differences and within-group differences. Significance of the AMOVA was determined using a null distribution obtained from 1023 nonparametric permutations. A Bonferroni correction for multiple tests was applied. Summary statistics including nucleotide diversity $(\pi)$ and haplotype diversity $(h)$ were also calculated for many of the groups in Arlequin. 


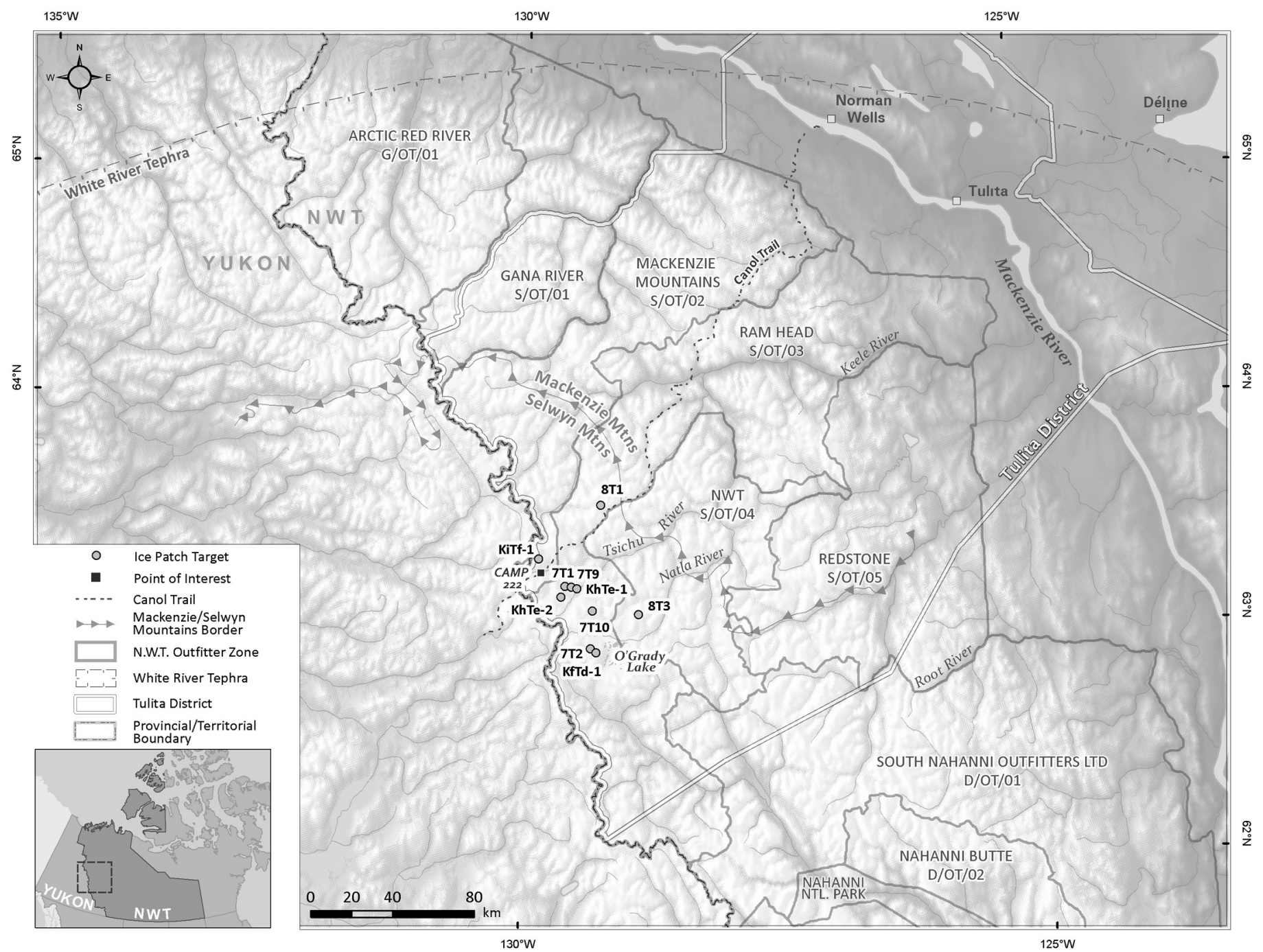

FIG. 2. The study area in the Mackenzie and Selwyn Mountains, NWT, indicating the locations of ice patches, the NWT outfitter zones, and the margins of the White River tephra (Lerbekmo, 2008).

TABLE 2. Summary of samples analyzed from each herd. Numbers shown below include sequences generated as part of this study and previously published sequences obtained from GenBank (Table 1).

\begin{tabular}{|c|c|c|c|c|c|c|}
\hline Subspecies & Territory or state & Herd (modern) & Ecotype (modern) & Migratory (modern) & $\mathrm{N}$ (modern) & $\mathrm{N}$ (ancient) \\
\hline \multirow[t]{6}{*}{ R.t. caribou } & NWT & Redstone & woodland & yes & 39 & 17 \\
\hline & YT & Wolf Lake & woodland & no & 1 & 1 \\
\hline & YT & Aishihik & woodland & no & 12 & 11 \\
\hline & YT & Ibex & woodland & no & 11 & 22 \\
\hline & YT & Aishihik/Ibex & woodland & no & 0 & 6 \\
\hline & YT & Carcross & woodland & no & 1 & 0 \\
\hline R.t. groenlandicus & NWT & unknown & barrenground & yes & 11 & 0 \\
\hline \multirow[t]{2}{*}{ R.t. granti } & YT and Alaska & Fortymile & barrenground & yes & 18 & 0 \\
\hline & Alaska & unknown & barrenground & yes & 12 & 0 \\
\hline
\end{tabular}

\section{RESULTS}

\section{DNA Sequencing Results and Ancient DNA Damage}

All new sequences have been deposited in GenBank under the accessions JF894172-JF894227 (Table 1). No non-caribou sequences were obtained in any cloning reactions, indicating the lack of PCR contamination. In one case, a nuclear mitochondrial insertion (numt) was observed. The closest match to this sequence retrieved by BLAST was an imperfect alignment to white-tailed deer, and as no deer had previously been handled in this lab, the sequence was assumed to be a caribou numt. In no case was the sequence found in other caribou amplifications. Cloning revealed varying degrees of DNA damage in all specimens, with an excess of $\mathrm{C}$ to $\mathrm{T}$ substitutions, as expected from 
88 B. LETTS et al.

(a)

\begin{tabular}{|c|}
\hline Legend \\
$-=1$ mutation \\
$=$ median vector \\
$=1$ individual \\
$=2$ individuals \\
$>3$ individuals are \\
marked in each circle
\end{tabular}
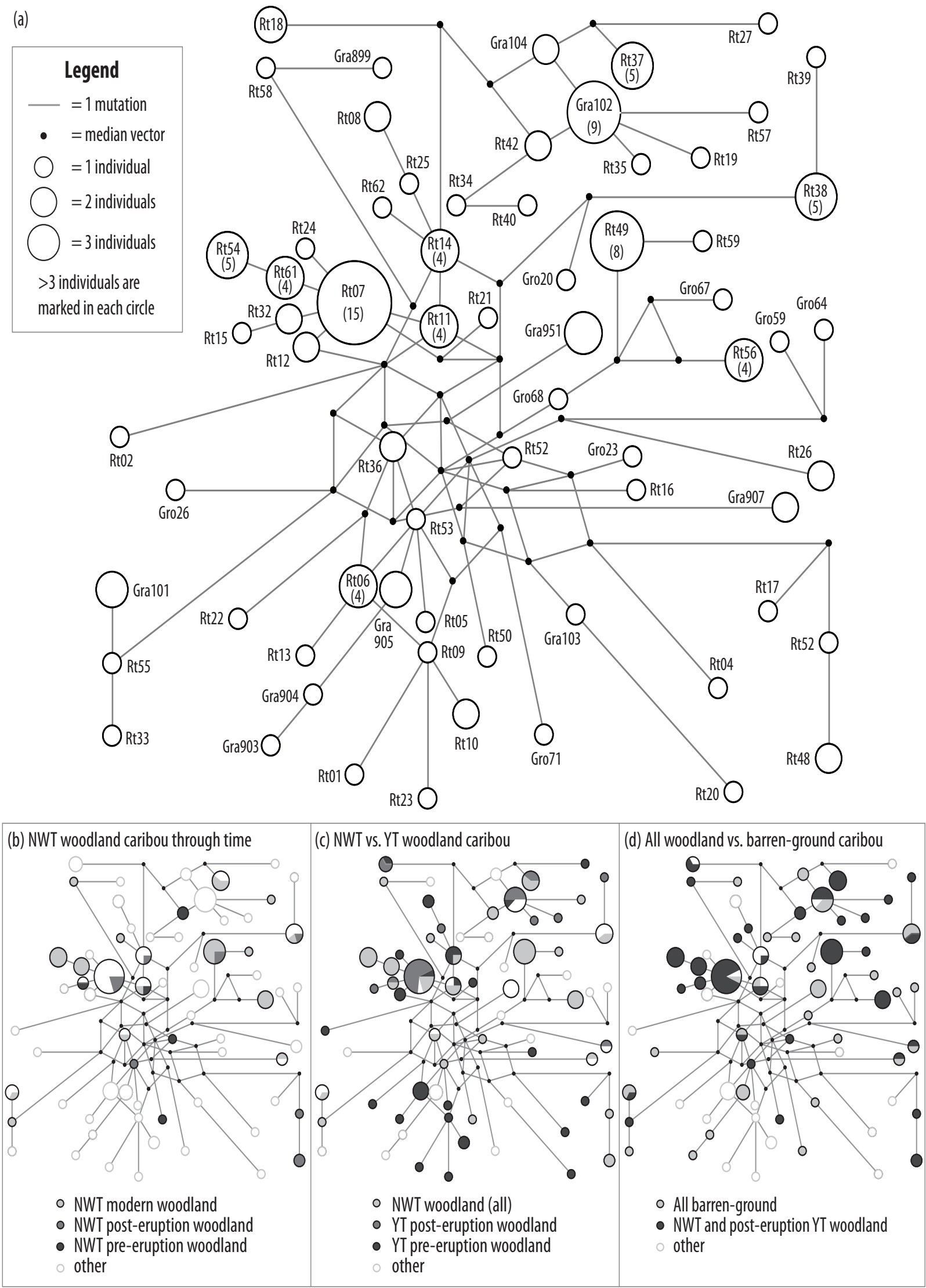

FIG. 3. Median-joining network of caribou mitochondrial haplotypes included in this study. (a) Unweighted median-joining network for all individuals included in this study that did not contain ambiguous bases or excess levels of missing data. Haplotype numbers (Table 1) are indicated for each circle, and circle size indicates the number of observations of each haplotype. (b-d) The network in (a) is shaded to highlight individuals relevant to three questions addressed in the text. 
cytosine deamination in ancient DNA molecules (Hofreiter et al., 2001; Gilbert et al., 2006).

\section{Genetic Analysis}

To test whether the Redstone herd is actually composed of multiple herds with overlapping ranges, we examined the relationships among caribou haplotypes identified by Network and BEAST. Well-defined clades could be indicative of herd fidelity. The median-joining network (Fig. 3) and the MCC tree (Fig. 4) revealed very little genetic structure in YT and NWT caribou.

To test the next three hypotheses, we performed FST and AMOVA calculations to examine the degree of genetic differentiation between predefined groups (Table 3). To assess whether ancient caribou from the ice patches are the ancestors of the modern Redstone herd, we compared all ancient (ice patch samples older than modern) NWT caribou to all modern NWT mountain woodland caribou. An FST score of 0.042 indicated little differentiation between the two groups. The AMOVA suggested that ancient and modern NWT caribou were not significantly differentiated $(p=0.0645)$ and that the majority of variation was due to within-group diversity $(96 \%)$, rather than to between-group differentiation. Furthermore, haplotype diversity $(h)$ in the NWT mountain woodland caribou did not change through time (ancient $h=0.923$, modern $h=0.963$, Table 4). On the basis of these results indicating that the NWT population is not significantly differentiated through time, all NWT mountain woodland caribou were treated as a single population for all subsequent analyses.

To test whether NWT caribou were affected by the deposition of the White River tephra, we again assumed two subpopulations, representing caribou living in the region before and after the deposition event around 1200 years ago. No genetic difference was detected between these two groups using either FST $(0.0)$ or AMOVA ( $p=$ 0.4106). To compare our results with those of Kuhn et al. (2010), we performed a similar set of tests using the previously published data set of Yukon caribou. In agreement with their results, we found an FST value of 0.169 , indicating moderate differentiation (Wright, 1978) between caribou inhabiting the Yukon before and after the eruption. An AMOVA showed that $17 \%$ of the total genetic variation was explained by differences between the pre- and post-eruption groups and was highly significant $(p=0.0)$. Haplotype diversity (Table 4 ) in the caribou inhabiting the area of the ice patches after the eruption $(h=0.851)$ was lower than that in the population inhabiting the area before the eruption $(h=0.977)$. In addition to these results, we found significant differentiation (FST $=0.108-0.138$, AMOVA $p=0.0$, Table 2) between mountain woodland caribou in the NWT and both pre- and post-eruption YT populations.

To test whether barren-ground and mountain woodland caribou ecotypes are genetically distinct from each other in the NWT, we compared modern barren-ground caribou to ancient and modern mountain woodland caribou from the study area. Ancient caribou from the ice patches were assumed to be woodland, as only mountain woodland caribou use the ice patches during summer months. The two ecotypes appear significantly differentiated in the NWT (FST $=0.082$, AMOVA $p=0.0068)$. A similar result $(\mathrm{FST}=0.041$, AMOVA $p=0.0020$ ) was obtained when all individuals in the study were included except the pre-eruption YT caribou, which appear significantly genetically differentiated from all modern caribou in our study. Both mountain woodland vs. barren-ground comparisons are significant at $p=0.05$ when Bonferroni correction for 7 tests is applied $(p<0.00714)$.

\section{DISCUSSION}

\section{Redstone Herd Identity}

Miller (1982) described a herd as an aggregation of caribou that remained together for at least a major portion of the year, and in which all breeding females shared an affinity for specific calving grounds not used by females from other herds. Three mountain woodland herds are defined in the Mackenzie Mountains of the NWT (Lortie, 1982). From north to south, they are the Bonnet Plume herd, the Redstone herd, and the South Nahanni herd (Fig. 1). The Redstone caribou herd is one of the largest woodland herds in Canada, numbering 5000 to 10000 individuals (Olsen et al., 2001). The Redstone herd occupies a summer range along the border with the Yukon near Macmillan Pass. During the winter, the herd ranges from the eastern slopes of the Mackenzie Mountains to the Redstone, Keele, and Moose Horn river basins. However, groups of several thousand animals have also been observed in this winter range during July and August (Veitch et al., 2000), which could suggest that more than one herd is living within the Redstone herd range. We do not observe any distinct clusters in either the Network (Fig. 3) or BEAST (Fig. 4) analyses, indicating that the Redstone herd likely represents a single large, diverse population. Although no groupings corresponding to outfitter zones are seen, using such large areas as kill localities may mask the observation of smaller geographic groupings. In the future, it will be important to record more specific kill locations, when feasible, in order to determine if any genetic structure exists within the Redstone range.

\section{The White River Tephra and Caribou Displacement}

The White River tephra is an ash layer resulting from the second Holocene eruption of the Bona-Churchill volcanic complex in southern Alaska around 1200 years ago (West and Donaldson, 2002; Froese et al., 2007; Lerbekmo, 2008). The eruption resulted in an ashfall over as much as one million $\mathrm{km}^{2}$ of land in Alaska, the Yukon, British Columbia, and the NWT (Lerbekmo, 2008). The thickness of the ash ranged from dozens of meters in Alaska to just a few millimeters at its farthest extent near Great Slave Lake, NWT (Lerbekmo, 2008). 
$90 \cdot$ B. LETTS et al.

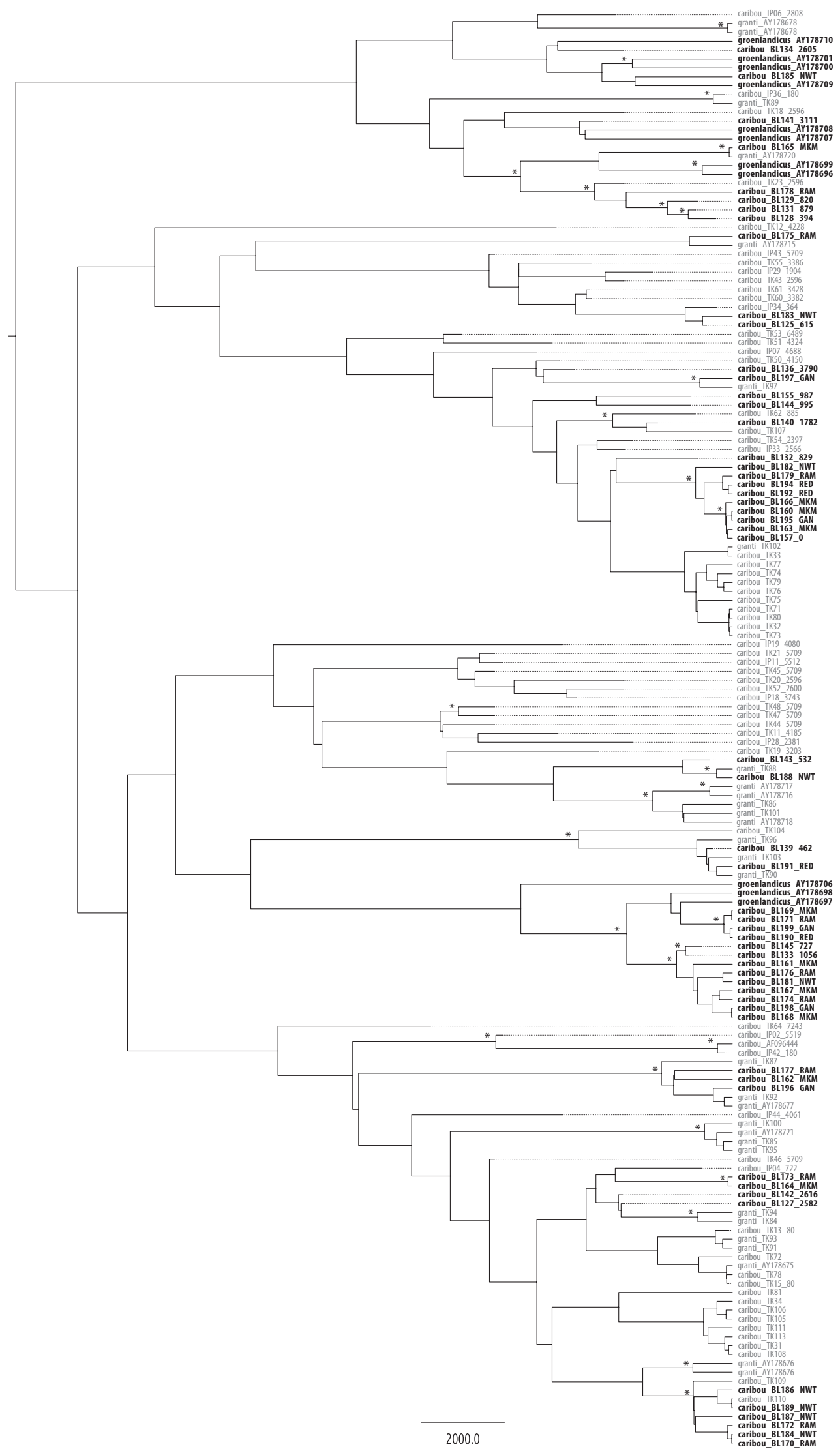

FIG. 4. Maximum Clade Credibility (MCC) tree from the BEAST analysis described in the text. Stars indicate posterior support values equal to 0.90 or greater. Individuals in black originated in the NWT, while those in gray originated in the YT or Alaska. Tips are labeled with subspecies, sample name, and age (years BP) of ancient samples, or with outfitter zone for modern NWT samples. Abbreviations for outfitter zones: RED $=$ Redstone, RAM $=$ Ram Head, MKM $=$ Mackenzie Mountains, NWT $=$ Northwest Territories, and GAN $=$ Gana River. 
TABLE 3. Analysis of Molecular Variance (AMOVA) results for four tests of North American caribou populations. Asterisks indicate significant values $(*=p<0.05, * *=p<0.01$, as determined after Bonferroni correction).

\begin{tabular}{|c|c|c|c|c|c|c|c|}
\hline \multicolumn{3}{|l|}{ Test } & $\begin{array}{c}\mathrm{N} \\
\text { per group }\end{array}$ & \multicolumn{4}{|c|}{$\begin{array}{c}\text { AMOVA } \\
\% \text { of variation explained by diversity }\end{array}$} \\
\hline \multicolumn{8}{|c|}{ Is the NWT woodland caribou population stable through time? } \\
\hline \multicolumn{4}{|c|}{ Pre vs. Post Eruption $\left(\sim 1200 \mathrm{ya}^{1}\right)$} & 0.000 & 0 & 100 & $0.4106 \pm 0.0139$ \\
\hline \multicolumn{3}{|c|}{ Ancient (330-3790 ya) vs. Modern } & $32 / 17$ & 0.042 & 4 & 96 & $0.0645 \pm 0.0074$ \\
\hline \multicolumn{8}{|c|}{ Is the YT woodland caribou population stable through time? } \\
\hline \multicolumn{3}{|c|}{ Pre vs. Post Eruption $(\sim 1200$ ya) } & $33 / 32$ & 0.169 & 17 & 83 & $0.0000 \pm 0.000^{* *}$ \\
\hline \multicolumn{8}{|c|}{ Are the NWT and YT woodland caribou genetically distinct (i.e., Are NWT woodland caribou a potential source population of modern YT woodland caribou)? } \\
\hline NWT ye Poct-Fruntion YT & uption YT & & $49 / 32$ & 0.138 & 14 & 86 & $0.0000 \pm 0.000^{* *}$ \\
\hline \multicolumn{3}{|c|}{ NWT vs. Pre-Eruption YT } & $49 / 33$ & 0.108 & 11 & 89 & $0.0000 \pm 0.000^{* *}$ \\
\hline \multicolumn{8}{|c|}{ Are the barren-ground and woodland caribou genetically distinct? } \\
\hline \multirow{2}{*}{\multicolumn{3}{|c|}{$\begin{array}{l}\text { All (NWT \& < 1200 ya YT/Alaska) barrengroun } \\
\text { NWT barren-ground vs. NWT woodland }\end{array}$}} & s. woodland 42/82 & 0.041 & 4 & 96 & $0.0020 \pm 0.0014 *$ \\
\hline & & & $11 / 49$ & 0.082 & 8 & 92 & $0.0068 \pm 0.0027^{*}$ \\
\hline \multicolumn{8}{|l|}{${ }^{1}$ ya $=$ years ago.} \\
\hline \multicolumn{8}{|c|}{$\begin{array}{l}\text { TABLE } 4 \text {. Diversity statistics for caribou groups discussed in text. Pre- and post-eruption refer to the White River ashfall around } 1200 \\
\text { years ago (ya). }\end{array}$} \\
\hline Subspecies & Province & Group & Age range (ya) & $\mathrm{N}^{1}$ & No. haplotypes & $\begin{array}{l}\text { Haplotype } \\
\text { diversity }(h)\end{array}$ & $\begin{array}{l}\text { Nucleotide } \\
\text { diversity }(p i)\end{array}$ \\
\hline \multirow[t]{2}{*}{ R.t. caribou } & NWT & modern & 0 & 32 & 16 & 0.923 & 0.017 \\
\hline & & ancient & $3790-394$ & 17 & 13 & 0.963 & 0.016 \\
\hline \multirow{3}{*}{$\begin{array}{l}\text { R.t. groenlandicus } \\
\text { R.t. caribou }\end{array}$} & NWT & all & 0 & 11 & 11 & 1.000 & 0.020 \\
\hline & YT & pre-eruption & $6489-1904$ & 33 & 25 & 0.977 & 0.013 \\
\hline & & post-eruption & $885-0$ & 32 & 12 & 0.851 & 0.014 \\
\hline R.t. granti & YT & all & 0 & 30 & 19 & 0.961 & 0.018 \\
\hline
\end{tabular}

${ }^{1}$ Total is lower than in Table 2 because some individuals with missing data were removed.

An analysis of caribou remains from ice patches in the southern YT suggested that the ashfall may have displaced caribou from the Southern Lakes region (Kuhn et al., 2010). After the ashfall, caribou are not found in the Southern Lakes region for 400 years, after which a genetically distinct population of caribou appears (Table 3). Like the Yukon ice patches, NWT ice patches were within the depositional range of the White River tephra (Fig. 2). Our results indicate, however, that the ashfall had no effect on the sampled NWT caribou, or, if it did, the population recovered quickly with no introgression from outside caribou herds or loss of genetic variation (Tables 3,4). This result is perhaps not surprising, as caribou are known to dig down or "crater" for food in snow depths of up to $120 \mathrm{~cm}$ (Johnson et al., 2001). As the layers of ash deposited around the NWT ice patches were less than $5 \mathrm{~cm}$ thick, and the ashfall occurred when there was already significant snow in the region (West and Donaldson, 2002), the deposition may have gone largely unnoticed by these caribou.

\section{Genetic Differentiation between NWT and YT Caribou}

Mountain woodland caribou are strongly tied to their home ranges, and mixing between herds is unlikely without range overlap (Zittlau, 2004). Studies have also shown that mountains (Zittlau, 2004) and rivers (McLoughlin et al., 2004) reduce gene flow in caribou. We therefore expected to see genetic differences between caribou herds on opposite sides of the Mackenzie and Selwyn Mountains. Our results comparing populations in the YT and NWT indicate significant differentiation at a moderate level between caribou in the two territories (Table 3). The observed divergence could be the result of the Mackenzie and Selwyn Mountains acting as a barrier to gene flow. However, because the Redstone herd crosses the mountains each year (Olsen et al., 2001), it is more likely that the genetic differentiation is a product of the geographic distance between the caribou herds analyzed here. These herds do not overlap in range, and in some cases they are separated by large distances (Fig. 1). Data from the Tay River and Finlayson herds, whose ranges overlap that of the NWT Redstone herd (Fig. 1), are needed for a more robust assessment of whether the mountains act as a genetic barrier for caribou.

We were also interested in determining whether or not the NWT mountain woodland caribou could represent a potential source population for the modern YT northern mountain woodland caribou that moved into the southwest YT after the White River ashfall. The NWT mountain woodland caribou are significantly different from preand post-eruption YT populations occupying the modern 
Aishihik and Ibex herd region (Table 3), making them an unlikely source population for the modern YT caribou in the those herds.

\section{Genetic Differentiation Based on Ecotype}

The distinction between barren-ground and woodland caribou is based on lifestyle and morphology (Banfield, 1961). Today, morphology is a controversial means of classification, as characters such as antler size and shape can be influenced by factors like variation in nutrition (Geist, 2007). The most obvious difference between the ecotypes is their lifestyle, with barren-ground caribou generally congregating in massive, migratory herds on the open tundra, and woodland caribou generally in smaller, sedentary herds within the boreal coniferous forests.

Three broad mitochondrial haplogroups have been identified across the holarctic range of the seven Rangifer tarandus subspecies (caribou and reindeer), hypothesized to correspond to three refugia (Flagstad and Røed, 2003). Haplogroup I comprises primarily southern woodland caribou (R. t. caribou), likely stemming from a southern North American refugium. Haplogroup II contained some European tundra reindeer (R. t. tarandus), possibly from a western Eurasian refugium. The widespread haplogroup III included individuals of all subspecies, but its primarily northern North American composition indicates a recent Beringian origin (Flagstad and Røed, 2003). All of the northern woodland haplotypes recovered in this study and by Kuhn et al. (2010) fall within haplogroup III. Interestingly, this fact illustrates that the northern and southern woodland caribou (R. t. caribou) are quite genetically distinct, as the northern woodland caribou appear to have originated from a Beringian refugium, along with the continental tundra forms (R. t. tarandus, granti, and groenlandicus) and Arctic forms (Svalbard reindeer, $R$. $t$. platyrhynchus, and Peary caribou, pearyi). The genetic distinction between northern and southern woodland caribou provides further evidence that the present species and subspecies-level designations are not supported by mitochondrial data on a holarctic scale. However, mitochondrial DNA is only maternally inherited, and bi-parentally inherited nuclear markers may shed more light on the degree of genetic differentiation between groups.

In contrast, our more focused and extensive sampling within a single geographic location showed that barrenground and mountain woodland caribou populations of the NWT are significantly genetically differentiated from one another (Table 3). This finding is consistent with previously identified allele frequency differences between the two ecotypes in North America (Cronin et al., 2005). Yet, there remains a very high degree of mitochondrial haplotype similarity between the two ecotypes (Figs. 3, 4), suggesting that insufficient time has lapsed for complete lineage sorting to occur within haplogroup III (Flagstad and Røed, 2003).

A low level of mixing between barren-ground and mountain woodland caribou cannot be discounted to explain the degree of haplotype similarity observed here. Barren-ground caribou generally calve on the open tundra and migrate below the tree line into the boreal forest during the winter. Given the geographic distance from our study area to the tree line, which has been east of Great Slave Lake and Great Bear Lake during the entire period of our study (Moser and Macdonald, 1990) and north of the Richardson Mountains, there is little chance of contact between the mountain woodland caribou in our sampling area and the barren-ground caribou herds from north of the tree line. Despite this low probability of contact, stray barren-ground caribou venturing into the boreal forest as far as our study region could be responsible for the incomplete differentiation between the ecotypes analyzed here.

\section{CONCLUSIONS}

Using ancient and modern DNA isolated from samples collected from alpine ice patches, we explore the recent history of the mountain woodland caribou inhabiting the central Mackenzie and Selwyn Mountains of the NWT, Canada. Our results suggest that the Redstone herd has been robust to environmental change over the past 4000 years, having withstood Holocene environmental events without the loss of genetic variation. We find significant genetic differentiation between mountain woodland and barrenground ecotypes in our study area, and between mountain woodland caribou in the NWT and YT. It appears that these ecotypes share a relatively recent common ancestor that is distinct from southern woodland caribou, but they have long lived separately, which has led to population genetic and ecological differentiation. Our mitochondrial results suggest that the mountain woodland caribou of the NWT and YT may represent a unique group within Rangifer tarandus, but further research incorporating more quickly evolving nuclear DNA markers is required to determine the extent and significance of this genetic differentiation.

\section{ACKNOWLEDGEMENTS}

Funding for this work was provided by the Searle Scholars Program, the Canadian International Polar Year Program, and NSF ARC-0909456. Thanks to Keri McFarlane and Alasdair Veitch for discussion on caribou genetics and to Greg Wilson and two anonymous reviewers whose comments helped to improve this manuscript. Also thanks to Amy Barker for assistance with mapping and making Figure 2.

\section{REFERENCES}

Andrews, T.D., MacKay, G., and Andrew, L. 2012. Archaeological investigations of alpine ice patches in the Selwyn Mountains, Northwest Territories, Canada. Arctic 65(Suppl. 1):1-21. 
Bandelt, H.J., Forster, P., and Röhl, A. 1999. Median-joining networks for inferring intraspecific phylogenies. Molecular Biology and Evolution 16(1):37-48.

Banfield, A.W.F. 1961. A revision of the reindeer and caribou, genus Rangifer. Bulletin 177. Ottawa: National Museum of Canada, Dept. of Northern Affairs and National Resources.

Bergerud, A.T. 1974. Decline of caribou in North America following settlement. Journal of Wildlife Management 38(4):757-770.

Cooper, A., and Poinar, H.N. 2000. Ancient DNA: Do it right or not at all. Science 289(5482):1139.

COSEWIC (Committee on the Status of Endangered Wildlife in Canada). 2002. COSEWIC assessment and update status report on the woodland caribou Rangifer tarandus caribou in Canada. Gatineau, Québec: COSEWIC.

Cronin, M.A., MacNeil, M.D., and Patton, J.C. 2005. Variation in mitochondrial DNA and microsatellite DNA in caribou (Rangifer tarandus) in North America. Journal of Mammalogy 86(3):495-505.

Drummond, A.J., and Rambaut, A. 2007. BEAST: Bayesian evolutionary analysis by sampling trees. BMC Evolutionary Biology 7:214.

Excoffier, L., and Lischer, H.E.L. 2010. Arlequin suite ver 3.5: A new series of programs to perform population genetics analyses under Linux and Windows. Molecular Ecology Resources 10:564-567.

Farnell, R., Hare, P.G., Blake, E., Bowyer, V., Schweger, C., Greer, S., and Gotthardt, R. 2004. Multidisciplinary investigations of alpine ice patches in southwest Yukon, Canada: Paleoenvironmental and paleobiological investigations. Arctic 57(3):247-259.

Flagstad, Ø., and Røed, K.H. 2003. Refugial origins of reindeer (Rangifer tarandus L.) inferred from mitochondrial DNA sequences. Evolution 57(3):658-670.

Froese, D.G., Buck, C.E., Clague, J.J., Koch, J., McColl, L., and Stothers, R.B. 2007. A Bayesian age estimate for the late Holocene White River-eastern lobe and its probable historical record. Canadian Quaternary Association Conference, 4-8 June, Carleton University, Ottawa, Ontario.

Geist, V. 2007. Defining subspecies, invalid taxonomic tools, and the fate of the woodland caribou. Rangifer Special Issue $17: 25-28$.

Gilbert, M.T.P., Binladen, J., Miller, W., Wiuf, C., Willerslev, E., Poinar, H., Carlson, J.E., Leebans-Mack, J.H., and Schuster, S.C. 2006. Recharacterization of ancient DNA miscoding lesions: Insights in the era of sequencing-by-synthesis. Nucleic Acids Research 35(1):1-10.

Guindon, S., and Gascuel, O. 2003. A simple, fast, and accurate algorithm to estimate large phylogenies by maximum likelihood. Systematic Biology 52(5):696-704.

Hasegawa, M., Kishino, H., and Yano, T.A. 1985. Dating of the human ape splitting by a molecular clock of mitochondrial DNA. Journal of Molecular Evolution 22(2):160 - 174.

Hinkes, M.T., Collins, G.H., Van Daele, L.J., Kovach, S.D., Aderman, A.R., Woolington, J.D., and Seavoy, R.J. 2005. Influence of population growth on caribou herd identity, calving ground fidelity, and behavior. Journal of Wildlife Management 69(3):1147-1162.

Hofreiter, M., Jaenicke, V., Serre, D., von Haeseler, A., and Pääbo, S. 2001. DNA sequences from multiple amplifications reveal artifacts induced by cytosine deamination in ancient DNA. Nucleic Acids Research 29(23):4793 - 4799.

Ion, P.G., and Kershaw, G.P. 1989. The selection of snowpatches as relief habitat by woodland caribou (Rangifer tarandus caribou), Macmillan Pass, Selwyn/Mackenzie Mountains, NWT Canada. Arctic and Alpine Research 21(2):203-211.

Johnson, C.J., Parker, K.L., and Heard, D.C. 2001. Foraging across a variable landscape: Behavioral decisions made by woodland caribou at multiple spatial scales. Oecologia 127(4):590-602.

Kuhn, T.S., McFarlane, K.A., Groves, P., Mooers, A.Ø., and Shapiro, B. 2010. Modern and ancient DNA reveal recent partial replacement of caribou in the southwest Yukon. Molecular Ecology 19(7):1312 - 1323.

Leonard, J.A. 2008. Ancient DNA applications for wildlife conservation. Molecular Ecology 17(19):4186-4196.

Lerbekmo, J.F. 2008. The White River Ash: Largest Holocene Plinian tephra. Canadian Journal of Earth Sciences 45(6):693-700.

Lortie, G.M. 1982. The 1981-1982 winter distribution of woodland caribou in the Mackenzie Mountains, NWT. Whitehorse: Yukon Renewable Resources.

McLoughlin, P.D., Dzus, E., Wynes, B., and Boutin, S. 2003. Declines in populations of woodland caribou. Journal of Wildlife Management 67(4):755-761.

McLoughlin, P.D., Paetkau, D., Duda, M., and Boutin, S. 2004. Genetic diversity and relatedness of boreal caribou populations in western Canada. Biological Conservation 118(5):593-598.

Miller, F.L. 1982. Management of barren-ground caribou (Rangifer tarandus groenlandicus) in Canada. In: Wemmer, C.M., ed. Biology and management of the Cervidae. Washington, D.C.: Smithsonian Institution Press. 523-534.

Moser, K.A., and Macdonald, G.M. 1990. Holocene vegetation change at treeline north of Yellowknife, Northwest Territories, Canada. Quaternary Research 34(2):227-239.

Olsen, B., MacDonald, M., and Zimmer, A. 2001. Co-management of woodland caribou in the Sahtu Settlement Area: Workshop on research, traditional knowledge, conservation and cumulative impacts Special Publication 1. Tulita, Northwest Territories: Sahtu Renewable Resources Board.

Posada, D. 2008. jModelTest: Phylogenetic model averaging. Molecular Biology and Evolution 25(7):1253-1256.

Rambaut, A. 2002. Se-al v2.0a11. Available at http://tree.bio.ed.ac. uk/software/seal/.

Reimer, P.J., Baillie, M.G.L., Bard, E., Bayliss, A., Beck, J.W., Blackwell, P.G., and Bronk Ramsey, C., et al. 2009. IntCal09 and Marine09 radiocarbon age calibration curves, 0-50,000 years cal BP. Radiocarbon 51:1111-1150.

Rohland, N., Siedel, H., and Hofreiter, M. 2010. A rapid columnbased ancient DNA extraction method for increased sample throughput. Molecular Ecology Resources 10(4):677-683, doi: 10.1111/j.1755-0998.2009.02824.x. 
Rokas, A., Ladoukakis, E., and Zouros, E. 2003. Animal mitochondrial DNA recombination revisited. Trends in Ecology and Evolution 18(8):411-417.

Stuiver, M., and Reimer, P.J. 1993. Extended ${ }^{14} \mathrm{C}$ data base and revised CALIB $3.0{ }^{14} \mathrm{C}$ age calibration program. Radiocarbon 35(1):215-230.

Veitch, A.M., Popko, R.A., and Whiteman, N. 2000. Classification of woodland caribou in the central Mackenzie Mountains, Northwest Territories, August 1999. Manuscript Report 122. Norman Wells: Department of Resources, Wildlife and Economic Development, Sahtu Region, Government of the Northwest Territories.

Weir, B.S., and Cockerham, C.C. 1984. Estimating F-statistics for the analysis of population structure. Evolution 38(6):1358 - 1370.

West, K.D., and Donaldson, J.A. 2002. Resedimentation of the late Holocene White River tephra, Yukon Territory and Alaska. In: Emond, D.S., Weston, L.H., and Lewis, L.L., eds.
Yukon exploration and geology. Whitehorse: Exploration and Geological Services Division, Yukon Region, Indian and Northern Affairs Canada. 239-247.

Willerslev, E., and Cooper, A. 2005. Ancient DNA. Proceedings of the Royal Society B 272(1558):3-16.

Willis, K.J., and Birks, H.J.B. 2006. What is natural? The need for a long-term perspective in biodiversity conservation. Science 314(5803):1261-1265.

Wright, S. 1978. Evolution and the genetics of populations, Vol. 4: Variability within and among natural populations. Chicago: University of Chicago Press.

Yukon Geomatics. 2008. Caribou herd ranges, Yukon Territory. Whitehorse: Yukon Department of Environment.

Zittlau, K.A. 2004. Population genetic analysis of North American caribou (Rangifer tarandus). $\mathrm{PhD}$ thesis, University of Alberta, Edmonton, Alberta. 